\title{
Permeability of Hypogymnia physodes Extract Component-Physodic Acid through the Blood-Brain Barrier as an Important Argument for Its Anticancer and Neuroprotective Activity within the Central Nervous System
}

\author{
Elżbieta Studzińska-Sroka ${ }^{1, *(\mathbb{D})}$, Aleksandra Majchrzak-Celińska ${ }^{2}$ (D) Przemysław Zalewski ${ }^{1}$ (D), \\ Dominik Szwajgier ${ }^{3}{ }^{(D}$, Ewa Baranowska-Wójcik ${ }^{3}\left(\mathbb{D}\right.$, Marcin Żarowski ${ }^{4}$, Tomasz Plech ${ }^{5}$ and \\ Judyta Cielecka-Piontek ${ }^{1}$ (D)
}

1 Department of Pharmacognosy, Poznan University of Medical Sciences, Święcicki 4 Str, 60-781 Poznań, Poland; pzalewski@ump.edu.pl (P.Z.); jpiontek@ump.edu.pl (J.C.-P.)

2 Department of Pharmaceutical Biochemistry, Poznan University of Medical Sciences, Święcicki 4 Str, 60-781 Poznań, Poland; majchrzakcelinska@ump.edu.pl

check for updates

Citation: Studzińska-Sroka, E.; Majchrzak-Celińska, A.; Zalewski, P.; Szwajgier, D.; Baranowska-Wójcik, E.; Żarowski, M.; Plech, T.; Cielecka-

Piontek, J. Permeability of Hypogymnia physodes Extract Component-Physodic Acid through the Blood-Brain Barrier as an Important Argument for Its Anticancer and Neuroprotective Activity within the Central Nervous System. Cancers 2021, 13, 1717. https://doi.org/10.3390/ cancers13071717

Academic Editors: Raffaele Capasso and Barbara Romano

Received: 16 February 2021

Accepted: 1 April 2021

Published: 5 April 2021

Publisher's Note: MDPI stays neutral with regard to jurisdictional claims in published maps and institutional affiliations.

Copyright: (c) 2021 by the authors. Licensee MDPI, Basel, Switzerland. This article is an open access article distributed under the terms and conditions of the Creative Commons Attribution (CC BY) license (https:// creativecommons.org/licenses/by/ $4.0 /)$.
3 Department of Biotechnology, Microbiology and Human Nutrition, University of Life Sciences in Lublin, Skromna 8 Str, 20-704 Lublin, Poland; dominik.szwajgier@up.lublin.pl (D.S.); ewa.baranowska@up.lublin.pl (E.B.-W.)

4 Department of Developmental Neurology, Poznan University of Medical Sciences, Przybyszewski 49 Str, 60-355 Poznań, Poland; zarowski@ump.edu.pl

5 Department of Pharmacology, Medical University of Lublin, Chodźki 4a Str, Lublin, Poland; tomasz.plech@umlub.pl

* Correspondence: elastudzinska@ump.edu.pl

Simple Summary: Central nervous system (CNS) diseases, including tumors such as glioblastomas and neurodegenerative diseases, such as Alzheimer's disease, are some of the greatest challenges of modern medicine. Therefore, our study aimed to evaluate the anticancer and neuroprotective activity of the extract from a common European lichen Hypogymnia physodes and of its compound-physodic acid. The examined substances were cytotoxic against the glioblastoma cell lines A-172, T98G, and U138 MG. Both substances strongly inhibited hyaluronidase, and diminished cyclooxygenase-2 activity (H. physodes extract), enzymes expressed in patients with malignant glioma. Furthermore, H. physodes extract inhibited tyrosinase activity, the enzyme linked to neurodegenerative diseases. The tested substances exhibited antioxidant activity, however, acetylcholinesterase and butyrylcholinesterase inhibitory activity were not high. We proved that physodic acid can cross the blood-brain barrier. We conclude that physodic acid and $H$. physodes extract should be regarded as promising agents with anticancer, chemopreventive, and neuroprotective activities, especially concerning CNS.

Abstract: Lichen secondary metabolites are characterized by huge pharmacological potential. Our research focused on assessing the anticancer and neuroprotective activity of Hypogymnia physodes acetone extract (HP extract) and physodic acid, its major component. The antitumor properties were evaluated by cytotoxicity analysis using A-172, T98G, and U-138 MG glioblastoma cell lines and by hyaluronidase and cyclooxygenase-2 (COX-2) inhibition. The neuroprotective potential was examined using COX-2, tyrosinase, acetylcholinesterase (AChE), and butyrylcholinesterase (BChE) activity tests. Moreover, the antioxidant potential of the tested substances was examined, and the chemical composition of the extract was analyzed. For physodic acid, the permeability through the blood-brain barrier using Parallel Artificial Membrane Permeability Assay for the Blood-Brain Barrier assay (PAMPA-BBB) was assessed. Our study shows that the tested substances strongly inhibited glioblastoma cell proliferation and hyaluronidase activity. Besides, HP extract diminished COX-2 and tyrosinase activity. However, the AChE and BChE inhibitory activity of HP extract and physodic acid were mild. The examined substances exhibited strong antioxidant activity. Importantly, we proved that physodic acid crosses the blood-brain barrier. We conclude that physodic acid and $H$. physodes should be regarded as promising agents with anticancer, chemopreventive, and neuroprotective activities, especially regarding the central nervous system diseases. 
Keywords: Hypogymnia physodes; anticancer; chemopreventive and neuroprotective activity; bloodbrain barrier permeability

\section{Introduction}

Bioactive compounds from natural sources can be regarded as important agents that can potentially be applied in the prevention and treatment of human diseases. Many phytochemicals, e.g., resveratrol, curcumin or epigallocatechin gallate, inhibit pathological processes, thus protecting against the development of various human diseases [1-3]. Over the last 10 years, a dynamic increase in the rate of the central nervous system (CNS) diseases has been observed. Delicate alterations in the precise mechanisms regulating CNS homeostasis may lead to the progressive loss of structure or function of neurons, which is present in neurodegenerative diseases such as Alzheimer's (AD), or can cause malignant transformation of cells, leading to brain tumors. Glial tumors are especially formidable, since they are not only the most common primary brain tumors, but also the most aggressive ones-the median survival of glioblastoma, the most common type of glial tumor, is around 15 months [4] and has not measurably decreased despite huge scientific efforts and novel treatment modalities. Neurodegenerative diseases, such as AD or Parkinson's disease (PD), are also significant public health care challenges. They are understood as a chain of events leading to a gradual loss of neurons' functional properties and leading to the death of the nerve cells [5]. Due to the aging profile of society, they are currently one of the most critical therapeutic problems. There are no effective therapies for the illnesses mentioned above. Therefore, substances influencing their pathological mechanism, which could facilitate effective treatments, are constantly being sought and tested.

Various mechanisms are important in the development of CNS pathological changes. Oxidative stress and many other processes (for example, inflammation, mitochondrial dysfunction, apoptosis) are considered the cause of CNS diseases [4,6]. Reactive oxygen species (ROS), resulting among others, from the metabolic transformations of neurotransmitters can attack sensitive glial cells and neurons, leading to the damage of CNS structures $[7,8]$.

Hyaluronic acid (HA), anionic, nonsulfated glycosaminoglycan, is the main component of the brain extracellular matrix. It is synthesized by the hyaluronan synthase (HAS) family and degraded by hyaluronidase [9]. The degradation of HA by hyaluronidase can produce final fragments with different molecular weights. In glioblastoma, fragments $<20 \mathrm{kDa}$ and between 20 and $50 \mathrm{kDa}$ are the most abundant isoforms [9]. These isoforms were found to be associated with enhanced cancer cell proliferation and invasion capacities, as well as proinflammatory and proangiogenic properties [10].

Moreover, most brain tumors, including glial tumors of different grades (e.g., glioblastoma, astrocytoma, oligodendroglioma), and medulloblastoma, craniopharyngioma, ependymoma and neurinoma, express high levels of cyclooxygenase 2 (COX-2). In glioblastoma, COX-2 expression levels were found to correlate with many aggressive aspects of the disease, such as proliferation rate, glioma WHO grade, and poor prognosis [11]. Thus, COX-2 can also be regarded as a crucial target in brain tumor therapy.

Tyrosinase is another enzyme which is linked to neurodegenerative diseases, such as PD. It oxidizes the excess dopamine to produce dopamine quinones, highly reactive species which induce neural damage and cell death [12]. Therefore, tyrosinase inhibition is anticipated to provide a new therapy for neurodegenerative disorders.

Other enzymes important for proper CNS functions are acetylcholinesterase (AChE) and butyrylcholinesterase $(\mathrm{BChE})$, both hydrolyzing a neurotransmitter-acetylcholine. Inhibition of acetylcholine hydrolysis is beneficial in neurodegenerative disorders, such as $\mathrm{AD}$. Moreover, noncholinergic functions of $\mathrm{AChE}$ and $\mathrm{BChE}$, such as regulation of proliferation processes and impact on cellular adhesion are also essential in brain tumors. 
An important criterion for achieving action within the CNS is the penetration of compounds through the blood-brain barrier. Among the mechanisms of xenobiotics penetration through biological barriers, the prominent role is played by passive transport, which, according to the literature data, concerns $80-95 \%$ of substances [13]. Many natural substances are absorbed through passive transport, including flavonoid aglycones (e.g., naringenin) [14], anthocyanidins [15], as well as compounds present in fungi and lichens, usnic acid (dibenzofuran) [16], or norlobaridone (depsidone) [17].

Lichens are an important source of bioactive compounds with interesting and littleknown biological activities. The antimicrobial activity of lichens, their antioxidant, enzymeinhibiting, and anti-inflammatory properties were studied [18,19]. Their antitumor activity was also proved and tested in cancer cell lines and animal cancer models [20]. The neuroprotective properties of lichen compounds are a relatively new issue. The studies conducted so far have shown that secondary metabolites of lichens (including depsidones) have the neuroprotective potential. The literature describes fumaroprotocetraric acid (depsidone from Cetraria islandica), which, in the human neuroblastoma cell model (SH-SY5Y; neurons) and the astrocytoma cell line model (U373-MG; astrocytes), reduced the cytotoxicity induced by the oxidative stress [21]. The neuroprotective potential of lichens was also associated with the ability to inhibit cholinesterases present in the CNS, thus increasing the neurotransmitter's level [19].

Hypogymnia physodes, commonly occurring in Europe, is a lichen from the Parmeliaceae family. This species contains compounds from the group of depsides and depsidones (including physodic acid) (Figure 1), which probably determine its biological potential [22-24]. H. physodes possess antiproliferative, antioxidant, antibacterial, and anticancer properties $[20,25]$. Therein, physodic acid was found to inhibit the canonical Wnt pathway in colorectal cancer cells [26] and inhibited M-Phase Phosphoprotein 1 (MPP1), which is upregulated in various bladder cancer types [17].

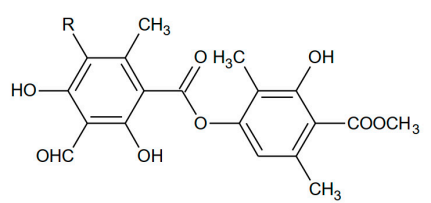

Atranorin $\mathrm{R}=\mathrm{H}$

Chloroatranorin $\mathrm{R}=\mathrm{Cl}$

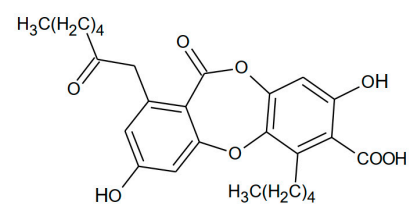

Physodic acid<smiles>CCOC(=O)Cc1cc(O)c(O)c2c1C(=O)Oc1cc(O)c(C(=O)O)c(CC)c1O2</smiles>

3-Hydroxyphysodic acid

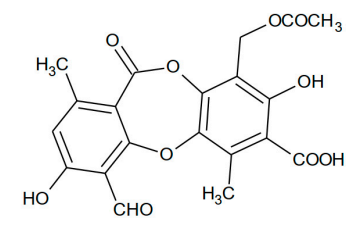

Physodalic acid

Figure 1. The main compounds present in Hypogymnia physodes.

Regarding the interesting but scant results on antiglioma and neuroprotective activity of lichens, we aimed to screen the biological activity of $H$. physodes acetone extract and physodic acid as the main compound isolated from its extract. The antitumor activity was assessed by examining the cytotoxicity of $H$. physodes acetone extract and physodic acid on A-172, T98G, and U-138 MG glioblastoma cell lines and by examination of hyaluronidase and cyclooxygenase-2 (COX-2) inhibitory properties. The neuroprotective potential was examined by measuring the antioxidant activity and by screening COX-2, tyrosinase, $\mathrm{AChE}$, and $\mathrm{BChE}$ inhibition. Moreover, we performed an in vitro PAMPA-BBB assay to assess the ability of physodic acid to cross the blood-brain barrier. 


\section{Materials and Methods}

\subsection{Plant Material}

H. physodes was manually collected in June 2015 in Jastrzębsko Stare, Poland, and authenticated by Dr. Daria Zarabska-Bożejewicz (The Institute for Agricultural and Forest Environment of Polish Academy of Sciences in Poznan, Bukowska 19, 60-809 Poznań, Poland). A voucher specimen (ES 2015.007) has been deposited in the herbarium of the Department of Pharmacognosy at Poznan University of Medical Sciences, Święcicki 4, 60-781 Poznań, Poland.

\subsection{Chemicals and Solvents}

Formic acid, hydrochloric acid, sodium carbonate, sodium hydroxide, DMSO, acetone, ammonium acetate, copper (II) chloride were purchased from Avantor Performance Materials Poland S.A. (Gliwice, Poland). The Folin-Ciocalteu's phenol reagent was from Merck (Darmstadt, Germany), HPLC grade water, HPLC grade acetonitrile, and acetate buffer were from the JT Baker-Avantor Performance Materials B.V. (Deventer, The Netherlands), tannic acid from Roth GmbH (Karlsruhe, Germany).

Physodic acid, the mixture of atranorin and chloroatranorin were isolated and identified in the Department of Pharmacognosy of Poznan University of Medical Sciences [26]. Atranorin was purchased from ChromaDex (Los Angeles, CA, USA). All other chemicals were obtained from Sigma-Aldrich (Taufkirchen, Germany).

\subsection{Preparation of Extract}

Dried, cleaned, and fragmented thalli of $H$. physodes $(10.0 \mathrm{~g})$ were sonicated at $35^{\circ} \mathrm{C}$ for $6 \times 30 \mathrm{~min}$ with acetone $(200 \mathrm{~mL} \times 6)$ in an ultrasonic bath. The extracts were filtered using Whatman filter paper No. 1 and concentrated by evaporation using a rotary evaporator under vacuum at $35-40{ }^{\circ} \mathrm{C}$ to afford a solid residue $(1.179 \mathrm{~g})$. The yield of the acetone extract was $11.79 \%$.

\subsection{Determination of Cytotoxicity of Physodic Acid and H. Physodes Acetone Extract}

T98G glioblastoma multiforme cell line was purchased from the European Collection of Authenticated Cell Cultures (ECACC, Salisbury, UK), whereas A-172 and U-138 MG were obtained from American Type Culture Collection (ATCC). These three particular glioblastoma cell lines were chosen for the analysis since they differ in the expression level of the O-6-methylguanine-DNA methyltransferase (MGMT), which is considered as one of the most important predictive biomarkers in glioblastoma patients [27]. These cell lines also differ in the sensitivity to temozolomide, the most commonly used alkylating agent. MGMT is not expressed in A-172, which is therefore regarded as temozolomide sensitive. Contrarily, T98G and U-138 MG cells express MGMT and are temozolomide resistant [28]. All cell lines were cultivated in recommended media, namely, line A-172 was grown in ATCC- formulated Dulbecco's modified Eagle's medium (DMEM) (SigmaAldrich, St. Louis, MO, USA), whereas T98G and U-138 MG were cultivated in ATCCformulated Eagle's Minimum Essential Medium (EMEM) (Sigma-Aldrich, St. Louis, MO, USA), respectively. The media were supplemented with $10 \%$ fetal bovine serum (FBS) and $1 \%$ antibiotics solution (penicillin and streptomycin). The medium for T98G cell line was additionally supplemented with $2 \mathrm{mM}$ glutamine, $1 \%$ nonessential amino acids and $1 \%$ sodium pyruvate. For all the experiments, the media containing all the above-listed reagents were used, but the amount of FBS was reduced to 5\%. All of the above-mentioned reagents, except FBS, were purchased from Sigma-Aldrich (USA). FBS was obtained from Biowest (Nuaillé, France). Cells from all three cell lines were incubated at $37^{\circ} \mathrm{C}$ in an atmosphere consisting of $95 \%$ air and $5 \% \mathrm{CO}_{2}$ in a humidified incubator until they reached $70 \%$ confluency, and then they were split.

Physodic acid was dissolved in dimethylsulfoxide (DMSO, Sigma-Aldrich, St. Louis, $\mathrm{MO}, \mathrm{USA}$ ) to make a $20 \mathrm{mM}$ stock solution stored at $-20^{\circ} \mathrm{C}$. The dry $\mathrm{H}$. physodes acetone extract was diluted in DMSO to make a $10 \mathrm{mg} / \mathrm{mL}$ stock solution. For the experiments, 
the stock solutions were diluted ex tempore to the final selected concentration with the complete cell culture medium containing 5\% FBS. The effect of physodic acid on the viability of A-172, T98G and U-138 MG cells was assessed by the MTT assay according to a standard protocol. Cells $\left(1 \times 10^{4}\right.$ per well $)$ were seeded in wells of a 96-well plate, and after $24 \mathrm{~h}$ of preincubation, increased concentrations of physodic acid $(0.47-47 \mu \mathrm{g} / \mathrm{mL}$ equal $1-100 \mu \mathrm{M})$ or $H$. physodes extract $(1-100 \mu \mathrm{g} / \mathrm{mL})$ were added, and cells were grown for $48 \mathrm{~h}$ at $37^{\circ} \mathrm{C}$. Cells treated with medium containing a respective concentration of DMSO (Sigma-Aldrich, St. Louis, MO, USA) were used as a control. After $48 \mathrm{~h}$, the cells were washed with $200 \mu \mathrm{L}$ of PBS, followed by incubation with 3-(4,5-dimethylthiazolyl-2)-2,5 diphenyltetrazolium bromide (MTT) solution (Merck, Darmstadt, Germany) in 10\% FBS medium $(0.5 \mathrm{mg} / \mathrm{mL})$ for $3 \mathrm{~h}$. After the incubation, MTT solution was removed from the wells, and acidic isopropanol was added. The plates were transferred to the orbital shaker to enhance dissolution of formazan crystals. Finally, the absorbance was measured at $\lambda=570 \mathrm{~nm}$ and $\lambda=690 \mathrm{~nm}$ on the microplate reader (Tecan Infinite M200). All the experiments were repeated three times with four measurements per assay.

\subsection{Anti-Hyaluronidase Activity}

Inhibition of hyaluronidase by the $H$. physodes extract was determined by a method described by Grabowska et al. [29] with minor modifications. Briefly, $25 \mu \mathrm{L}$ of incubation buffer (50 mM, pH 7.0, with $77 \mathrm{mM} \mathrm{NaCl}$ and $1 \mathrm{mg} / \mathrm{mL}$ of albumin), $25 \mu \mathrm{L}$ of enzyme (30 U/mL of acetate buffer $\mathrm{pH} 7.0), 10 \mu \mathrm{L}$ solutions of the examined acetone extract (1.875$0.3125 \mathrm{mg} / \mathrm{mL})$ or physodic acid $(1.25-0.3125 \mathrm{mg} / \mathrm{mL})$, and $15 \mu \mathrm{L}$ of acetate buffer $(\mathrm{pH} 4.5)$ were combined (the final concentrations were $0.1875-0.03125$ and $0.125-0.03125 \mathrm{mg} / \mathrm{mL}$, for extract and physodic acid, respectively). The samples were incubated at $37^{\circ} \mathrm{C}$ for $15 \mathrm{~min}$. Next, $25 \mu \mathrm{L}$ of HA $\left(0.3 \mathrm{mg} / \mathrm{mL}\right.$ in acetate buffer) was added. After incubation at $37^{\circ} \mathrm{C}$ for $45 \mathrm{~min}$ $200 \mu \mathrm{L}$ of $2.5 \%$ cetrimonium bromide (CTAB) in $2 \% \mathrm{NaOH}$ was added to undigested HA precipitated. The turbidity of the reaction mixture was measured as the absorbance at $600 \mathrm{~nm}$ (Multiskan GO 1510, Thermo Fisher Scientific, Vantaa, Finland) after $10 \mathrm{~min}$ of incubation at room temperature. Tannic acid was used as the positive control $(6.0-1.25 \mathrm{mg} / \mathrm{mL}$, with the final concentration $0.6-0.125 \mathrm{mg} / \mathrm{mL}$ ). For the investigated substances, three independent experiments were carried out, and the average from $n=5$ measurements was calculated. The percentage of inhibition was calculated by using the equation below.

$$
\% \text { inhibition activity }=\frac{\left(\mathrm{T}_{\mathrm{s}}-\mathrm{TE}_{\text {blank }}\right)}{\left(\mathrm{TH}_{\text {blank }}-\mathrm{TE}_{\text {blank }}\right)} \times 100 \%
$$

where $\mathrm{T}_{\mathrm{S}}$ - absorbance of sample; $\mathrm{TE}_{\mathrm{blank}}$ - absorbance of the enzyme + examined substance; $\mathrm{TH}_{\text {blank }}$-absorbance of the $\mathrm{HA}+$ examined substance.

\subsection{Anticyclooxygenase Activity}

H. physodes extract or isolated physodic acid (prepared as described above) were dissolved in DMSO (for molecular biology, Sigma-Aldrich D8418) to obtain $9.12 \mathrm{mg} / \mathrm{mL}$ $(456 \mu \mathrm{g} / \mathrm{mL}$ final concentration) and $6.00 \mathrm{mg} / \mathrm{mL}(300 \mu \mathrm{g} / \mathrm{mL})$, respectively. These stock solutions were tested undiluted as well as diluted (with DMSO) 1.5-fold and 3-fold. For the assay, reagents from Cayman COX Activity Assay Kit (Chemical, Ann Arbor, MI, USA, No. 760151) were prepared as suggested by the producer and combined with COX-2 enzyme (Human recombinant, Cayman No. 60122, pre-diluted 100-fold using 100 mM, pH 8.0 Tris buffer). A volume of $0.01 \mathrm{~mL}$ of a diluted sample was mixed with $0.01 \mathrm{~mL}$ hemin, shaken and left for $5 \mathrm{~min}$ at $25{ }^{\circ} \mathrm{C}$ followed by addition of $0.02 \mathrm{~mL}$ colorimetric substrate, $0.02 \mathrm{~mL}$ arachidonic acid solution and completed to $0.18 \mathrm{~mL}$ using Tris buffer $(100 \mathrm{mM}$, $\mathrm{pH}$ 8.0). To start the reaction, $0.02 \mathrm{~mL}$ of COX-2 solution was added. The increase of the absorbance during the incubation at room temperature was recorded at $590 \mathrm{~nm}$ after $20 \mathrm{~min}$ (Tecan microplate reader, Grödig, Austria). Negative (blank) sample (0.01 mL Tris buffer instead of the studied sample) and positive sample (COX-2 inhibitor DuP-697) were run simultaneously. Background of the studied samples $(0.01 \mathrm{~mL}$ of the sample mixed with 
$0.19 \mathrm{~mL}$ Tris buffer) was also measured and included in the calculations. Each sample was run in at least four repeats.

\subsection{Anti-Tyrosinase Activity}

Tyrosinase inhibitory activity was determined by a spectrophotometric method, as described by Lim et al. [30] with some modifications. A $12.8 \mathrm{mg}$ of the acetone extract from $H$. physodes or physodic acid was weighed, dissolved in $1 \mathrm{~mL}$ of DMSO, and used to obtain 6.4 and $3.2 \mathrm{mg} / \mathrm{mL}$ concentrations. Next, $25 \mu \mathrm{L}$ of prepared concentrations was added to $75 \mu \mathrm{L}$ of $0.1 \mathrm{M}$ phosphate buffer $(\mathrm{pH} 6.8)$ and $50 \mu \mathrm{L}$ of tyrosinase solution $(192 \mathrm{U} / \mathrm{mL}$ in distillate water). After the incubation at room temperature $\left(25^{\circ} \mathrm{C}, 10 \mathrm{~min}\right), 50 \mu \mathrm{L}$ of L-DOPA $(2 \mathrm{mM})$ was added and incubated for the next at the same temperature condition $\left(25^{\circ} \mathrm{C}\right.$, $20 \mathrm{~min})$. Each sample was accompanied by a blank that contains all components except LDOPA. The control sample contained DMSO instead of the test substance. Absorbance was measured at $475 \mathrm{~nm}$. The azelaic acid solution (12.8-3.2 $\mathrm{mg} / \mathrm{mL}$ prepared in DMSO) was used as the positive control. For the investigated substances, two independent experiments were carried out and the average from $n=4$ measurements was calculated. The percentage of tyrosinase inhibition was calculated as:

$$
\% \text { tyrosinase inhibition }=\frac{\mathrm{A}_{\text {control }}-\mathrm{A}_{\text {sample }}}{\mathrm{A}_{\text {control }}} \times 100 \%
$$

where $A_{\text {control }}$ is absorbance of control sample without blank; $A_{\text {sample }}$ is absorbance of tested sample without blank.

\subsection{Anticholinesterase Activity}

Ellman's colorimetric method was used [31] with some modifications described previously [32]. Tested sample $(5 \mu \mathrm{L}$, at the concentration of $5 \mathrm{mg} / \mathrm{mL}$-final concentration in the mixture: $72.5 \mu \mathrm{g} / \mathrm{mL}$ ) was mixed with $20 \mu \mathrm{L}$ of AChE (or BChE) solution $(0.28 \mathrm{U} / \mathrm{mL}$ ) and completed after $5 \mathrm{~min}$ with $35 \mu \mathrm{L}$ of ATChI (or BTCh) $(1.5 \mathrm{mmol} / \mathrm{L}), 175 \mu \mathrm{L}$ of $0.3 \mathrm{mmol} / \mathrm{L}$ DTNB (containing $10 \mathrm{mmol} / \mathrm{L} \mathrm{NaCl}$ and $2 \mathrm{mmol} / \mathrm{L} \mathrm{MgCl}_{2}$ ) and $110 \mu \mathrm{L}$ with Tris- $\mathrm{HCl}$ buffer $(50 \mathrm{mmol} / \mathrm{L}, \mathrm{pH} 8.0)$. Samples containing $5 \mu \mathrm{L}$ of Tris-HCl buffer instead of the studied sample were run in the same way ("blank" samples). The increase in absorbance due to the spontaneous hydrolysis of the substrate was monitored using "blank" samples containing ATCh (or BTCh) and DTNB completed to $345 \mu \mathrm{L}$ with Tris-HCl buffer. The effect of DMSO on the enzyme activity was tested using $5 \mu \mathrm{L}$ of DMSO instead of the tested sample. All samples were incubated at $22{ }^{\circ} \mathrm{C}$ (30 min, incubation time was determined after optimization experiments, details not shown), and the absorbance was measured (405 nm, 96-well microplate reader, Tecan Sunrise, Grödig, Austria).

The "false-positive" effect of studied compounds was measured according to Rhee et al. [33] with minor modifications, as described previously [32]. After mixing the substrate with the enzyme and buffer, the "false-positive" sample was left for incubation. Then, a studied sample and DTNB were added, followed by an immediate measurement of the absorbance.

Reference cholinesterase inhibitors were used for the calculations of results (eserine, and donepezil). For this purpose, for each compound, 16 dilutions in pure DMSO were prepared $(0.09-1.44 \mu \mathrm{g} / \mathrm{mL})$. These solutions were tested as described above, and calibration curves were calculated.

Each sample was analyzed in at least eight repeats, and all solutions used in a set of analyses were prepared in the same buffer. For calculations, the background of the sample ( $5 \mu \mathrm{L}$ mixed with $340 \mu \mathrm{L}$ of Tris buffer) was measured at $405 \mathrm{~nm}$ and subtracted during calculations. Then, the absorbance of the test sample was subtracted from the absorbance of the "blank" sample.

\subsection{Antioxidant Activity}

The CUPric Reducing Antioxidant Capacity (CUPRAC) assay was performed according to Kikowska et al. [34] with modifications. The stock solutions of CUPRAC reagent 
included equal parts of acetate buffer ( $\mathrm{pH}$ 7.0), $7.5 \mathrm{mM}$ neocuproine solution in $96 \%$ ethanol, and $10 \mathrm{mM} \mathrm{CuCl}_{2} \mathrm{xH}_{2} \mathrm{O}$ solution. Briefly, $0.05 \mathrm{~mL}$ of the dry extract or compound solution dissolved in DMSO at different concentrations $(24-96$ and $60-1000 \mu \mathrm{g} / \mathrm{mL}$ for the extract and physodic acid, respectively), was mixed with $0.15 \mathrm{~mL}$ of CUPRAC solution (the final assay concentrations were 6-24 and $15.0-250 \mu \mathrm{g} / \mathrm{mL}$, for the extract and physodic acid, respectively), shaken and incubated at room temperature for $30 \mathrm{~min}$ in the dark conditions. Then the absorbance was read at $450 \mathrm{~nm}$. Vitamin $C$ and resveratrol were used as a standard $(4-64 \mu \mathrm{g} / \mathrm{mL})$; the final assay concentrations were $1-16 \mu \mathrm{g} / \mathrm{mL}$, for vitamin $\mathrm{C}$, and $25-400 \mu \mathrm{g} / \mathrm{mL}$; the final assay concentrations were $6.25-100 \mu \mathrm{g} / \mathrm{mL}$ for resveratrol. For the investigated substances, three independent experiments were carried out, and the average from $n=6$ measurements was calculated. The results were expressed as the $\mathrm{IC}_{0.5}$ which corresponds to the extract concentration required to produce 0.5 absorbance value.

\subsection{Total Phenolic Content (TPC)}

TPC was determined using the Folin-Ciocalteu method [35]. In total, $0.1 \mathrm{~mL}$ of the extract, dissolved in DMSO at concentration $2 \mathrm{mg} / \mathrm{mL}$, was mixed with $4.0 \mathrm{~mL}$ of distilled water and with $0.5 \mathrm{~mL}$ of Folin-Ciocalteu reagent. After $1 \mathrm{~min}, 2.0 \mathrm{~mL}$ of $20 \%$ sodium carbonate was added and supplemented with distilled water to a total volume of $10 \mathrm{~mL}$. The absorbance was measured at $760 \mathrm{~nm}$, after $30 \mathrm{~min}$ incubation at dark and at room temperature. A blank sample of water and reagents was used as a reference. TPC was expressed as $\mathrm{mg}$ of gallic acid equivalent per $\mathrm{g}$ of a dry extract (a calibration curve of gallic acid: $\left.y=9.8399 x+0.0289 ; R^{2}=0.9993\right)$ in a concentration range $0.02-0.08 \mathrm{mg} / \mathrm{mL}$.

\subsection{High-Performance Liquid Chromatography (HPLC) Analysis}

A gradient HPLC method with UV detection was developed and validated for the determination of compounds from extracts. The extracts were dissolved in acetonitrile at concentration $0.4 \mathrm{mg} / \mathrm{mL}$. A Kinetex C18 column $(100 \times 2.1 \mathrm{~mm}, 5 \mu \mathrm{m})$ was used as the stationary phase. The mobile phase consisted of acetonitrile and $0.5 \%$ formic acid with a flow rate of $0.3 \mathrm{~mL} / \mathrm{min}$. The initial concentration of acetonitrile was $5 \%$, then it increased to $100 \%$ during $10 \mathrm{~min}$. In the next step, isocratic elution with $100 \%$ acetonitrile was proceeded for $2 \mathrm{~min}$. Finally, during $5 \mathrm{~min}$ the concentration of acetonitrile was decreasing to initial conditions (5\%). The detection wavelength was $254 \mathrm{~nm}$, and the temperature was $40{ }^{\circ} \mathrm{C}$. The method was validated with regard to selectivity, linearity, precision, limit of detection, limit of quantitation for physodic acid, and atranorin.

\subsection{Permeability through the Blood-Brain-Barrier (PAMPA-BBB)}

To evaluate the effective permeability $(\mathrm{Pe})$ of the H. physodes extract and physodic acid, the Parallel Artificial Membrane Permeability Assay (PAMPA) for the Blood-Brain Barrier (BBB) was used (Pion Inc., Billerica, MA, USA). The stock solutions of acetone extract from $H$. physodes and from physodic acid were prepared with DMSO $(3 \mathrm{mg} / 0.1 \mathrm{~mL}$ or $1.5 \mathrm{mg} / 0.1 \mathrm{~mL}$, respectively) and diluted with Prisma buffer $(\mathrm{pH}=7.4$; from Prisma HT, Pion Inc.) to obtain the donor solutions for physodic acid: $0.45 \mathrm{mg} / \mathrm{mL}$ (30 $\mu \mathrm{L}$ of stock $/ 1000 \mu \mathrm{L}$ of buffer for physodic acid) or $0.9 \mathrm{mg} / \mathrm{mL}$ ( $60 \mu \mathrm{L}$ of stock $/ 1000 \mu \mathrm{L}$ of buffer for physodic acid), and $0.9 \mathrm{mg} / \mathrm{mL}$ ( $30 \mu \mathrm{L}$ of stock $/ 1000 \mu \mathrm{L} \mathrm{H}$. physodes acetone extract). Then, $180 \mu \mathrm{L}$ of the donor solution were added to the donor wells. Subsequently, each filter membrane of the top plate was coated with $5 \mu \mathrm{L}$ BBB-1 lipid solution (Pion Inc.) and the acceptor well was filled with $200 \mu \mathrm{L}$ BSB (Brain Skin Buffer, Pion Inc.). The acceptor plate and the donor plate were sandwiched together and incubated for $4 \mathrm{~h}$ at $37^{\circ} \mathrm{C}$. After incubation, the sandwiched plates were separated, and concentrations were determined using the HPLC method (HPLC Prominence-i LC-2030C, Shimadzu) [36]. Effective permeability $(\mathrm{Pe})$ of the compounds was calculated by using the following equation:

$$
P_{e}=-\frac{\ln \left(1-\frac{\mathrm{C}_{\mathrm{A}}}{\mathrm{C}_{\mathrm{eq}}}\right)}{\mathrm{S} \times\left(\frac{1}{V_{\mathrm{D}}}+\frac{1}{\nabla_{\mathrm{A}}}\right) \times \mathrm{t}}
$$


where $P e$ is the effective permeability coefficient $(\mathrm{cm} / \mathrm{s}) ; \mathrm{V}_{\mathrm{D}}$-donor volume; $\mathrm{V}_{\mathrm{A}}$-acceptor volume; $C_{e q}$-equilibrium concentration, $C_{e q}=\frac{C_{D} \times V_{D}+C_{A} \times V_{A}}{V_{D}+V_{A}}$; $S-$ membrane area; $\mathrm{t}$-incubation time (in seconds).

Compounds with $P e\left(10^{-6} \mathrm{~cm} / \mathrm{s}\right)>1.5$ are classified as high permeation predicted, with $P e\left({ }^{*} 10^{-6} \mathrm{~cm} / \mathrm{s}\right)<1.5$ classified as low permeation predicted $[36,37]$. Samples were analyzed in triplicate and the average was reported.

\subsection{Statistical Analysis}

Statistical analysis was performed using GraphPad Prism ${ }^{\mathrm{TM}} 6.00$ software (Graph Pad Software Inc., San Diego, CA, USA). Results were expressed as means \pm SEM (standard error of the mean). The median effect concentrations $\left(\mathrm{IC}_{50}\right.$ or $\mathrm{IC}_{0.5}$ values) were determined using a concentration-response curve. Statistical differences were calculated using Tukey's HSD test (STATISTICA 13.0, StatSoft, Kraków, Poland) with significant differences considered at $p<0.05$.

\section{Results}

The experimental studies carried out as part of this study were divided into three areas: (i) screening of the pharmacological activity of the extract and physodic acid, (ii) evaluation of the composition of the extract, and identification of compounds responsible for its biological activity, and (iii) assessment of the ability to penetrate the blood-brain barrier of physodic acid in the PAMPA-BBB assay.

\subsection{Screening of Biological Activity}

The screening of biological effects of $H$. physodes extract and physodic acid was carried out in relation to (i) anticancer and (ii) neuroprotective properties.

\subsubsection{Cytotoxic Activity Against Glioblastoma Cells}

In order to determine the cytotoxicity of physodic acid and H. physodes extract, the MTT assay was used. As presented in Figure 2, A-172, T98G and U-138 MG cell lines treated with $0.47-47 \mu \mathrm{g} / \mathrm{mL}(1-100 \mu \mathrm{M})$ of physodic acid for $48 \mathrm{~h}$ responded to the treatment in a very similar manner. Even though the differences were not pronounced, U-138 MG cells were slightly more sensitive to the treatment with physodic acid, especially if it comes to the lowest tested concentration range $0.47-11.75 \mu \mathrm{g} / \mathrm{mL}(1-25 \mu \mathrm{M})$. The concentration of $0.47-$ $11.75 \mu \mathrm{g} / \mathrm{mL}(1-25 \mu \mathrm{M})$ did not significantly influence cells viability, however, $23.5 \mu \mathrm{g} / \mathrm{mL}$ $(50 \mu \mathrm{M})$ concentration reduced the percentage of living cells of A-172, T98G and U-138 MG cell lines to $33 \%, 51 \%$, and $42 \%$, respectively. The highest tested concentration, namely $100 \mu \mathrm{M}$ was cytotoxic to all analyzed cell lines. Similarly, $H$. physodes extract at the highest tested concentration of $100 \mu \mathrm{g} / \mathrm{mL}$ led to total cell death of all analyzed cell lines. In contrast, $50 \mu \mathrm{g} / \mathrm{mL}$ and its lower concentrations allowed the survival of $\sim 70 \%$, or even more cells. Interestingly, A-172 cell line was slightly more sensitive to $H$. physodes extract as compared to the other two cell lines. The $\mathrm{IC}_{50}$ values are presented in Table 1.

Table 1. The $\mathrm{IC}_{50}$ of cells viability after Hypogymnia physodes extract or physodic acid exposition.

\begin{tabular}{ccc}
\hline \multirow{2}{*}{ Type of Cells } & H. Physodes Extract & Physodic Acid \\
\cline { 2 - 3 } & IC $_{\mathbf{5 0}}[\boldsymbol{\mu g} / \mathbf{m L}]$ & IC $_{\mathbf{5 0}}[\boldsymbol{\mu g} / \mathbf{m L}(\boldsymbol{\mu M})]$ \\
\hline A-172 & $61.37 \pm 5.19$ & $19.95 \pm 0.59(42.41 \pm 1.25)$ \\
\hline T98G & $72.15 \pm 4.33$ & $23.79 \pm 0.51(50.57 \pm 1.09)$ \\
\hline U-138MG & $68.36 \pm 1.58$ & $21.51 \pm 1.98(45.72 \pm 4.20)$ \\
\hline
\end{tabular}

$\overline{\mathrm{IC}_{50}}$ is the mean values \pm SEM calculated from the curve plotted using three independent experiments with four measurements per assay. 
Hypogymnia physodes

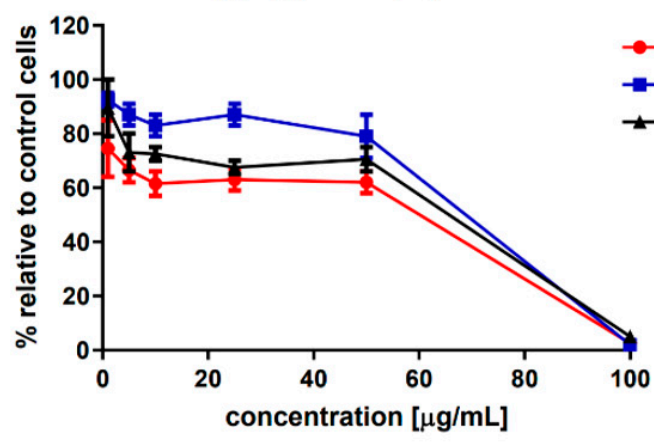

(A)
Physodic acid

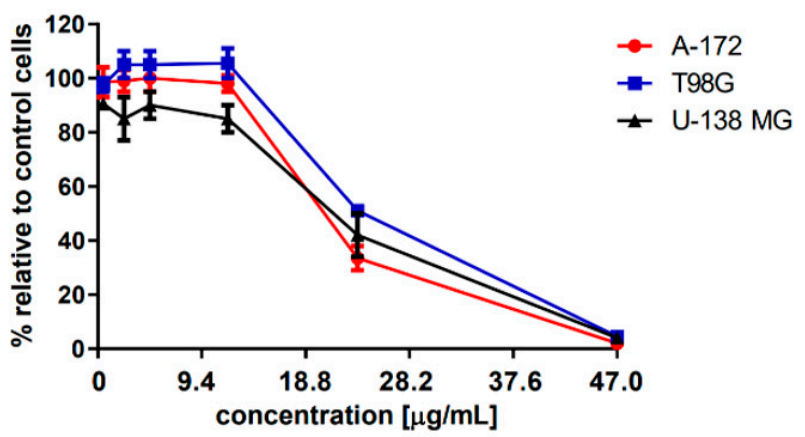

(B)

Figure 2. The effect of Hypogymnia physodes extract (A) and physodic acid (B) on the viability of A-172, T98G and U-138 MG cell lines. The mean values \pm SEM from three independent experiments with four measurements per assay are presented.

\subsubsection{Anti-Hyaluronidase Activity}

To evaluate the inhibitory effect of $H$. physodes extract and physodic acid on hyaluronidase activity, the in vitro method was used. The analysis has shown that both the extract and physodic acid have a high ability to inhibit the enzyme (Figure 3). Physodic acid $\left(\mathrm{IC}_{50}=0.053 \mathrm{mg} / \mathrm{mL}\right)$ was more active than $H$. physodes extract $\left(\mathrm{IC}_{50}=0.078 \mathrm{mg} / \mathrm{mL}\right)$. The compounds were from 6 to 10 times more active than the strong hyaluronidase inhibitortannic acid $\left(\mathrm{IC}_{50}=0.554 \mathrm{mg} / \mathrm{mL}\right)$. The results are obtained for the first time for the physodic acid and $H$. physodes extract.

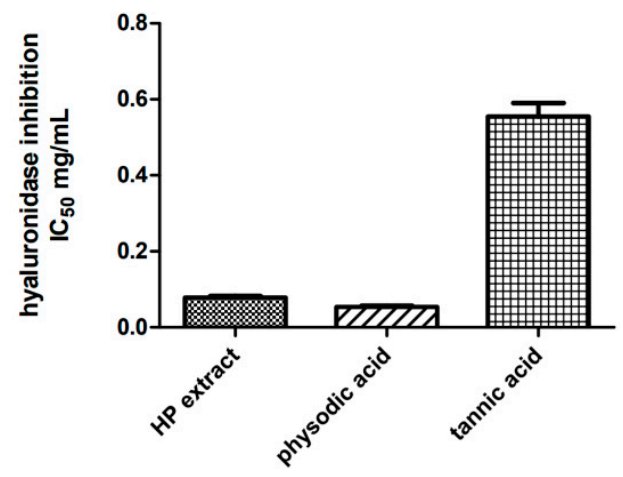

Figure 3. Inhibition of hyaluronidase by Hypogymnia physodic extract (HP extract), physodic acid and the references substance tannic acid. Results are presented as $\mathrm{IC}_{50}$ values $(\mathrm{mg} / \mathrm{mL}) \pm \mathrm{SEM}$, calculated from five measurments $(n=5)$ obtained from three independent experiments.

\subsubsection{Inhibition of COX-2}

The anti-inflammatory activity of $H$. physodes extract and physodic acid via the COX-2 inhibition analysis was estimated. The obtained results showed that among the two tested substances, the extract from $H$. physodes had the high activity of inhibiting the enzyme. $H$. physodes extract inhibited the COX-2 activity at the concentrations of 304 and $456 \mu \mathrm{g} / \mathrm{mL}$, respectively; however, the concentration of $152 \mu \mathrm{g} / \mathrm{mL}$ showed no inhibitory activity (Table 2). Physodic acid showed no inhibitory activity at the concentrations applied (100, 200 or $300 \mu \mathrm{g} / \mathrm{mL}$ ). The results of the study suggest that, in the model of anti-inflammatory activity selected for the experiment, the extract from $H$. physodes had promising properties. At the same time, the solutions of pure physodic acid turned out to be inactive. 
Table 2. Inhibition of cyclooxygenase-2 (COX-2) by Hypogymnia physodes extract (H. physodes extract) and physodic acid.

\begin{tabular}{cccc}
\hline \multicolumn{2}{c}{ Concentration (Final Concentration) } & \multicolumn{2}{c}{ Inhibition of COX-2 } \\
\hline H. physodes extract & Physodic acid & H. physodes extract & Physodic acid \\
\hline $152 \mu \mathrm{g} / \mathrm{mL}$ & $100 \mu \mathrm{g} / \mathrm{mL}$ & n.a. & n.a. \\
$304 \mu \mathrm{g} / \mathrm{mL}$ & $200 \mu \mathrm{g} / \mathrm{mL}$ & $28.60 \% \pm 2.4 \%$ & n.a. \\
$456 \mu \mathrm{g} / \mathrm{mL}$ & $300 \mu \mathrm{g} / \mathrm{mL}$ & $52.40 \% \pm 1.1 \%$ & n.a. \\
\hline
\end{tabular}

The mean values \pm SEM from four independent measurements, "n.a."—not active.

\subsubsection{Anti-Tyrosinase Activity}

The inhibition of tyrosinase, which is a popular target in drug research for PD, was estimated using in vitro method with L-DOPA as its substrate. The obtained results showed that the extract inhibits the enzyme in a dose-dependent manner (Figure 4). At a higher concentration (final concentration $1.6 \mathrm{mg} / \mathrm{mL}$ ), the tested sample inhibited the enzyme by $25 \%$. This activity was only about three times lower as compared to azelaic acid, a potent enzyme inhibitor used as a standard, and tested in the same concentration. The tyrosinase inhibitory activity of $H$. physodes extract, and physodic acid has not yet been described in the literature previously.

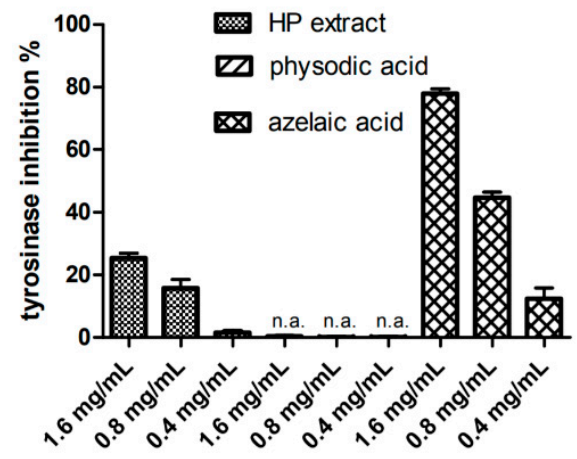

Figure 4. Inhibition of tyrosinase by Hypogymnia physodes extract (HP extract), physodic acid and the reference substance azelaic acid. The mean values \pm SEM from two independent experiments with two measurements per assay are presented $(n=4)$. "n.a."-not active.

\subsubsection{Anticholinesterase Activity}

To investigate the anticholinesterase effect (anti-AChE and anti-BChE) of H. physodes extract and physodic acid Ellman's analysis was effectuated. Both tested substances indicate a low capacity of inhibition of enzymes (AChE and BChE) (Table 3). Interestingly, the affinity of the tested substances for the type of cholinesterase differed depending on the type of enzyme. Physodic acid inhibited only BChE, while $H$. physodes extract acted solely on AChE.

Table 3. Inhibition of acetylcholinesterase (AChE) and butyrylcholinesterase (BChE) by Hypogymnia physodes extract (H. physodes extract) and physodic acid comparing with the reference substances.

\begin{tabular}{ccc}
\hline Materials for Studies & AChE & Inhibition of Enzyme \\
\hline $\begin{array}{c}\text { H. physodes extract } \\
72.5 \mu \mathrm{g} / \mathrm{mL} \\
\text { Physodic acid }\end{array}$ & $9.6 \pm 0.1 \%$ & BChE \\
\hline $2.5 \mu \mathrm{g} / \mathrm{mL}(154 \mu \mathrm{M})$ & n.a. & $8.1 \pm 0.2 \%$ \\
\cline { 2 - 3 } Inhibition similar to: & eserine at $0.12 \pm 0.007 \mu \mathrm{g} / \mathrm{mL}$ & eserine at $0.019 \pm 0.001 \mu \mathrm{g} / \mathrm{mL}$ \\
\hline
\end{tabular}




\subsubsection{Antioxidant Activity}

The assessment of antioxidant activity of H. physodes extract and physodic acid was performed by using CUPRAC method (not previously used for this purpose). In our study, the $\mathrm{IC}_{0.5}$ value for extract was $15.49 \mu \mathrm{g} / \mathrm{mL}$ and was only 1.5 times lower than the value characterizing vitamin $\mathrm{C}$ activity $\left(\mathrm{IC}_{0.5}=9.70 \mu \mathrm{g} / \mathrm{mL}\right)$. The activity of resveratrol whose multidirectional biological activity results from widely recognized antioxidant properties, was described by the value of $\mathrm{IC}_{0.5}=32.07 \mu \mathrm{g} / \mathrm{mL}$ and was almost two times lower than the activity of $H$. physodes extract. The tested $\mathrm{IC}_{0.5}$ for physodic acid was $160 \mu \mathrm{g} / \mathrm{mL}$. Thus, physodic acid had about five times lower antioxidant activity, as compared to resveratrol. The obtained results are presented below in Figure 5.

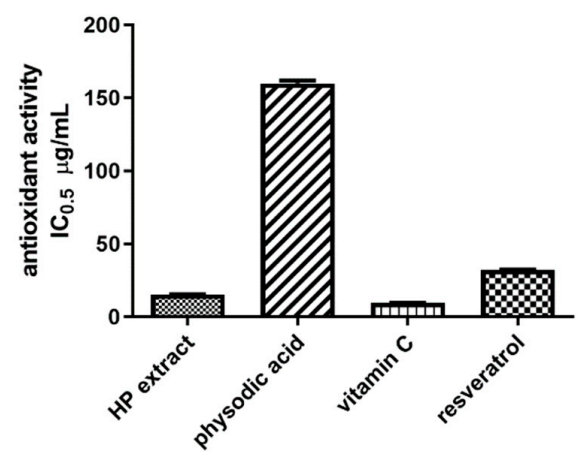

Figure 5. Antioxidant activity of $H$. physodes extract (HP extract), physodic acid, and the reference substances: resveratrol and vitamin C, measured in CUPRAC experiment. Results are presented as $\mathrm{IC}_{0.5}$ values $(\mu \mathrm{g} / \mathrm{mL})$ as the mean value $\pm \mathrm{SEM}$, the average from $n=6$ measurements was calculated.

\subsection{Phytochemical Analysis}

\subsubsection{Total Polyphenols Content (TPC)}

TPC was also determined in the tested extract using the Folin-Ciocalteu method. $H$. physodes extract was characterized by a significant content of phenolic compounds ( $289.90 \pm 3.68 \mathrm{mg}$ gallic acid equivalent/g of extract), which is equivalent to almost $29 \%$ of the compound with the phenolic structure.

\subsubsection{High-Performance Liquid Chromatography (HPLC) Analysis}

The best separation of the H. physodes extract was obtained for atranorin $\left(t_{R}=10.72 \mathrm{~min}\right)$, chloroatranorin $\left(t_{R}=11.06 \mathrm{~min}\right)$, and physodic acid $\left(t_{R}=9.66 \mathrm{~min}\right.$ ) (Figure 6) which were present in $H$. physodes extract when gradient elution (acetonitrile and $0.5 \%$ formic acid) on $5 \mu \mathrm{m}$ core-shell particles was applied. As a result of the optimization steps, the components of $H$. physodes extract were separated below $12 \mathrm{~min}$.

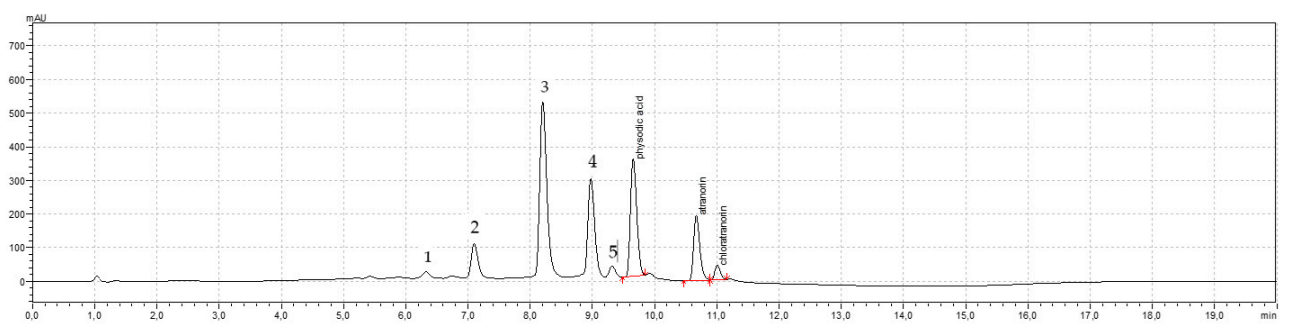

Figure 6. The chromatogram of extract from Hypogymnia physodes. Physodic acid, atranorin and chloroatranorin are identified in the extract. Compounds 1, 2, 3, 4, and 5, are characterized by $t_{R}=6.30,7.10,8.20,8.97$, and $9.32 \mathrm{~min}$, respectively.

Peaks were symmetrical, clearly separated from each other (resolution over 1.5). The method was linear from 0.009091 to $0.3 \mathrm{mg} / \mathrm{mL}(n=5, R=0.9982)$. The RSD values for intraday and interday precision were below $2 \%$, so the developed method was precise. The method was also accurate (the recovery value was around 100\%). 
The HPLC analysis of $H$. physodes extract confirmed that it contained $21.09 \%$ of physodic acid and $3.58 \%$ of atranorin. Chloroatranorin was qualitatively defined in the extract. For this purpose, atranorin as a reference and the mixture of both atranorin $\left(t_{R}=10.72 \mathrm{~min}\right)$ and chloroatranorin $\left(t_{R}=11.06 \mathrm{~min}\right)$ were used. Besides, the two peaks with the retention times $t_{R}=8.20 \mathrm{~min}$ and $t_{R}=8.97$ min strongly suggested the presence in the extract two other main depsidones of $H$. physodes: physodalic acid and 3-hydroxyphysodic acid. This finding is supported by various literature data [38-41]. In addition, more compounds were detected in the extract. Compounds marked as 1, 2, 3, 4, and 5, and characterized by $t_{R}=6.30,7.10,8.20,8.97 \mathrm{~m}$ and $9.32 \mathrm{~min}$, respectively. According to the literature data, these are most likely salazinic acid, protocetraric acid or alpha-alectoronic acid, and minimal amount other derivatives of physodic acid (4-O-methylphysodic acid or 2'-O-methylphysodic acid) [40].

\subsection{Permeability through the Blood-Brain-Barrier (PAMPA-BBB)}

For the investigation of the transcellular passive diffusion of physodic acid across the blood-brain barrier, the Parallel Artificial Membrane Permeability Assay PAMPA-BBB method was used. The solution of pure physodic acid, and the $H$. physodes extract were evaluated to determine the effective permeability coefficient $(\mathrm{Pe})$. As shown in Figure 7 , the permeability of physodic acid from the $H$. physodes extract was higher as compared to physodic acid from its pure compound solution. Moreover, the concentration in donor solution of physodic acid was higher for the pure compound than for the acetone extract (0.45-0.90 and $0.19 \mathrm{mg} / \mathrm{mL}$, respectively). Nevertheless, the permeability coefficient of both tested samples was regarded as high $\left(>1.5 \times 10^{-6} \mathrm{~cm} / \mathrm{s}\right)[36,37]$. Thus, both physodic acid itself, as well as physodic acid included in the $H$. physodes extract, can easily pass through the blood-brain barrier via passive diffusion. Furthermore, the chromatogram of the acceptor sample suggests the other compounds can penetrate CNS (Figure 8).

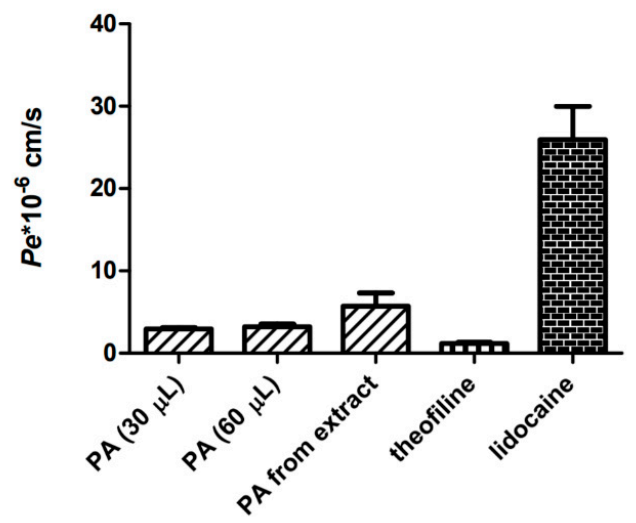

Figure 7. Permeability of pure physodic acid (PA) at different concentrations, physodic acid from extract (PA from extract), and the reference substances: theofiline and lidocaine, examined using PAMPA-BBB model. Results are presented as $P e^{*} 10^{-6} \mathrm{~cm} / \mathrm{s}$. The mean values $\pm \mathrm{SEM}$ from three independent experiments are presented $(n=3)$.

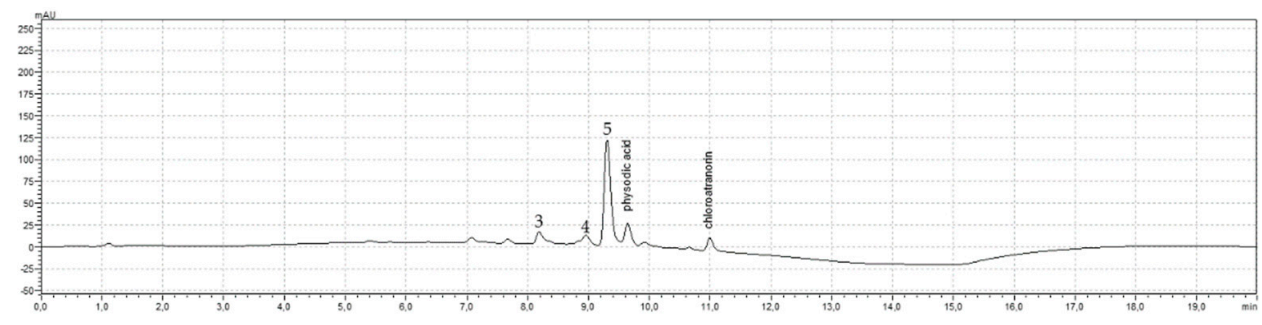

Figure 8. The chromatogram of acceptor solution of extract from Hypogymnia physodes. Physodic acid $\left(t_{R}=9.64 \mathrm{~min}\right)$ and chloroatranorin $\left(t_{R}=10.99 \mathrm{~min}\right)$ are the identified compounds visible in the acceptor chromatogram. Compounds 3,4 , and 5 are characterized by $t_{R}=8.19,8.96,9.31 \mathrm{~min}$, respectively. 


\section{Discussion}

Lichens are a great source of bioactive, phenolic compounds, including depsides, depsidones, anthraquinones, xanthones, and dibenzofuranes. Even though lichens have been used in traditional medicine for ages, the molecular mechanisms responsible for their cellular actions have only recently been evaluated and understood. In this regard, it has been shown that lichen-derived secondary metabolites can act as e.g., anticancer, antimicrobial, antiviral, anti-inflammatory, or antioxidant agents [17-20,42]. H. physodes is an especially interesting lichen, since it is widely distributed worldwide, providing a powerful natural source of compounds with potential pharmaceutical applications. In our previous study, we showed that $H$. physodes derived depsidone-physodic acid, was cytotoxic to HCT116 and DLD-1 colorectal cancer cells [26]. Moreover, it inhibited the expression of $\beta$-catenin-dependent genes and attenuated cell migration [26]. We also showed that physodic acid and $H$. physodes extract was cytotoxic to MDA-MB-231, MCF7 and T-47D breast cancer cell lines and that $H$. physodes extract possesses significant antioxidant activity [43].

Considering the attractive biological potential of $H$. physodes, we hypothesized that $H$. physodes acetone extract and its major components, physodic acid might possess biological properties important for glioblastoma treatment or neurodegenerative diseases treatment. The few studies in this area prompted us to undertake the work that attempts to fill this gap.

Glioblastoma is the most common primary brain tumor in adults [44]. Owing to the $\mathrm{BBB}$, which restricts the infiltration of most antitumor drugs into the CNS, the treatment of this deadly tumor involves maximal surgical resection, radiotherapy, and chemotherapy with temozolomide [44]. However, despite the best possible treatment, tumor recurrence is inevitable, so novel drug candidates or compounds that could ameliorate the treatment are urgently needed. Thus, we wanted to determine if physodic acid and H. physodes extract are cytotoxic to glioblastoma cell lines. Even though no clinical study has been conducted yet, there are a number of in vitro and in vivo studies demonstrating anticancer effects of lichen metabolites, including physodic acid [20]. In this study, three glioblastoma cell lines were used, namely A-172, T98G, and U-138 MG. The first mentioned cell line is regarded as temozolomide sensitive, whereas, the last two are temozolomide resistant [45]. Our results confirmed that physodic acid and $H$. physodes extract dose-dependently reduced the viability of all three glioblastoma cell lines, regardless of their temozolomide sensitivity. Physodic acid significantly reduced the viability of the tested cells at $23.5 \mu \mathrm{g} / \mathrm{mL}(50 \mu \mathrm{M})$ concentration, whereas $H$. physodes extract led to total cell death at $100 \mu \mathrm{g} / \mathrm{mL}$. However, in regard to $H$. physodes extract, we observed a decrease in cell viability even with the lowest concentrations tested $(1-10 \mu \mathrm{g} / \mathrm{mL})$, in particular in A-172 cell line. This phenomenon can potentially be explained by the fact that $H$. physodes extract, as shown in our HPLC analysis, contains not only physodic acid, but also various other chemicals, including atranorin, chloroatranorin, physodalic acid, and 3-hydroxyphysodic acid, and most likely also salazinic acid, protocetraric acid or alpha-alectoronic acid. The minimal amount of other derivatives of physodic acid (4-O-methylphysodic acid or 2'-O-methylphysodic acid) can also be present, influencing glioblastoma cell viability. In a study by Emsen et al. [22], cell viabilities of rat neuron cell line PRCC and human glioblastoma U87MG cells exposed to different concentrations of physodic acid were determined. The obtained $\mathrm{IC}_{50}$ values were 698.19 and $410.72 \mathrm{mg} / \mathrm{L}$ for PRCC cell line, and U87G cell lines, respectively, showing higher sensitivity of glioblastoma cells as compared to noncancerous neurons. Importantly, no cytotoxic effects were observed for physodic acid in a study on noncancerous astrocytes [46]. Furthermore, in another study, conducted on murine neuroblastoma Neuro2A cells, lichen-derived secondary metabolites including physodic acid and atranorin, displayed an important increase in neurite outgrowth [47]. Nevertheless, the potential impact of $H$. physodes extract on noncancerous astrocytes and neurons requires further investigation. 
Inhibition of certain enzymes is regarded as one of the therapeutic strategies for the management of cancer. Hyaluronidase-hyaluronic acid degrading enzyme is highly expressed in patients with malignant glioma [48]. It produces low molecular weight hyaluronic acid fragments, associated with enhanced invasion and increased tumor growth $[9,10]$. Thus, in this study we wanted to verify if physodic acid and H. physodes extract are able to inhibit hyaluronidase. Our results show that both analyzed substances can strongly inhibit hyaluronidase enzymatic activity, however, physodic acid was more active than H. physodes extract. Importantly, both of them were from 6 to 10 times more active than the potent inhibitor of hyaluronidase-tannic acid. Research on the ability to inhibit hyaluronidase by lichen secondary metabolites is minimal. The available results describe the activity only of usnic acid, the most commonly found secondary metabolite in lichens, which was lower than the tannic acid used as the standard [49]. No other results regarding lichen secondary metabolites or lichen extracts have been reported in the literature so far.

Our next goal was to establish the impact of physodic acid and H. physodes extract on COX-2 enzymatic activity. COX-2 is another overexpressed enzyme with a key function in glioblastoma. The molecular mechanisms by which COX-2 promotes tumorigenesis are not fully clear, but it is suggested that prostaglandin E2 (PGE2), produced by COX-2, facilitates tumor activities, including tumor cell adhesion, proliferation, migration, angiogenesis, immunosuppression, and metastasis [11]. Our study shows that $H$. physodes extract strongly inhibits COX-2 enzymatic activity, however, it is not physodic acid that exerts this action. Additionally, atranorin, one of the substances present in the extract, was not active at the chosen concentration of $1 \mathrm{mg} / \mathrm{mL}$ (unpublished data). Thus, we can speculate that the COX-2 inhibitory activity of $H$. physodes extract results either from the presence of physodic acid derivatives or potentially also synergistic effects of its compounds. This issue requires further investigation.

Even though we did not observe physodic acid COX-2 inhibitory activity, it is important to note that using pharmacophore models Bauer et al. [50] showed that this lichen metabolite inhibits microsomal prostaglandin E2 synthase-1. It is an inducible enzyme that is upregulated at various pathophysiological stages, including glioblastoma, and in conjunction with the inducible COX-2, produces massive amounts of PGE2 [51].

Apart from cancer, the involvement of COX-2 in neurodegenerative processes has also been established. Neuroinflammatory processes involving COX-2 overexpression and elevated PGE2 levels have been associated with several neurodegenerative diseases, including AD, PD, and amyotrophic lateral sclerosis (ALS) [52]. Moreover, another enzymetyrosinase, oxidizing excess dopamine to produce dopamine quinones, highly reactive species which induce neural damage and cell death, was also linked to PD and other neurodegenerative diseases. Our study provides evidence that $H$. physodes extract strongly inhibits not only COX-2, but also tyrosinase. Similar results were obtained by Higuchi et al. [53], who found that $H$. physodes methanol extract from in vitro culture tissue strongly inhibited tyrosinase activity. Moreover, the mycobiont of $H$. physodes showed higher inhibitory action (55.3\%) as compared to photobiont (22.4\%). In our study, we did not find any inhibitory activity of physodic acid on tyrosinase activity; therefore, we can speculate that other secondary metabolites present in this lichen are responsible for this action. However, no studies related to this issue were, to our best knowledge, published so far.

In our study, we also found a small influence of physodic acid and H. physodes extract on AChE and BChE activity. Both enzymes are druggable targets in AD. Thus, their inhibiton by the lichen compounds would be beneficial. Such effects were observed in a study of Stojanović et al. [54], who analyzed extract of Hypogymnia tubulosa. In this study, the extract inhibited cholinesterase to the extent of $23.6 \%$ at a concentration of $10 \mathrm{mg}$. In comparison, at a concentration of $1 \mathrm{mg}$ it showed a weak activation effect on cholinesterase to the extent of $3.3 \%$. On the other hand, Reddy et al. [46], similarly to our study, did not find any AChE activity of physodic acid. Further research is needed to fully elucidate the impact of physodic acid on AChE and BChE activity. 
The level of ROS in our body is kept at a constant level. However, excess free radicals cross the cell membrane, attacking sensitive glial cells and neurons, leading to irreversible damage important in degenerative changes of brain [7,8]. In our study, the H. physodes extract (a mixture of depsides and depsidones) had high antioxidant activity, higher (approx. 10 times) than the pure physodic acid. Studies on the antioxidant activity of $H$. physodes extracts, with the use of other than the CUPRAC method $[19,43,55]$ confirm the high activity of the examined extract. Taking into consideration that both physodic acid and H. physodes extract show high antioxidant activities, further research, aiming at the determination of the chemical composition of the extract, was undertaken.

The HPLC analysis of acetone extract of H. physodes confirmed that it contained physodic acid and atranorin and as well as the other compounds, probably chloroatranorin, physodalic acid, and 3-hydroxyphysodic acid. The percentage of physodic acid and atranorin in the acetone extracts of H. physodes from Jastrzębsko Stare, Poland were 21.09\% and $3.58 \%$, respectively. On the other hand, Solhaug reported the concentration of around $38 \%$ of physodic acid and $2.75 \%$ of atranorin in the acetone extract from $H$. physodes collected from Jeløya, Norway. The differences in the concentration values of detected substances are closely connected with the geographic region from which the samples came from [56].

A review of the literature shows that some natural substances can pass into the CNS by passive transport. They include, among others, quercetin and resveratrol, as well as lovastatin, which under natural conditions is produced by the fungus Pleurotus ostreatus $[57,58]$. There are no studies on the permeability of physodic acid through the blood-brain barrier using the PAMPA-BBB model. Our tests confirmed that both physodic acid as a single substance as well as physodic acid from $H$. physodes extract are both able to diffuse through the BBB. The permeability coefficient of both analyzed substances was regarded as high [36,37], meaning they can easily reach the CNS and potentially also brain tumor mass. Thus, they could successfully be used in the treatment of glioblastoma or neurodegenerative diseases.

\section{Conclusions}

The lack of effective therapy of neoplastic brain diseases and degenerative changes in the CNS indicates the need to search for new substances with a therapeutic potential. Our attempt to evaluate the antiglioma properties demonstrated cytotoxicity of H. physodes extract and physodic acid against glioblastoma cells. The ability to inhibit both hyaluronidase and COX-2 activity by $\mathrm{H}$. physodes extract and its active compound suggest properties that may lower tumor formation rate. The ability to inhibit tyrosinase and cholinesterase activity, and high antioxidant properties confirm the neuroprotective properties of the extract. Our study confirmed the anticancer, chemopreventive and neuroprotective properties of physodic acid and H. physodes extract. Nevertheless, in order to fully confirm their usefulness in the prevention and treatment of brain tumors and neurodegenerative diseases, more studies are needed, especially using cell cultures and animal models.

Author Contributions: Conceptualization, E.S.-S. and J.C.-P.; methodology, E.S.-S., A.M.-C., P.Z., D.S. and E.B.-W.; validation, P.Z.; formal analysis, E.S.-S.; P.Z., A.M.-C., D.S. and E.B.-W.; investigation, E.S.-S., P.Z., A.M.-C., D.S. and E.B.-W.; resources, J.C.-P., A.M.-C., D.S. and E.B.-W.; data curation, E.S.-S., A.M.-C., P.Z., D.S. and E.B.-W.; writing-original draft preparation, E.S.-S.; A.M.-C., P.Z., J.C.-P.; writing-review and editing, J.C.-P., E.S.-S., M.Ż., A.M.-C., T.P., D.S.; visualization: E.S.S., A.M.-C., P.Z.; supervision, P.Z., E.S.-S. and J.C.-P.; project administration, E.S.-S., P.Z., J.C.-P.; funding acquisition, J.C.-P. and T.P. All authors have read and agreed to the published version of the manuscript.

Funding: This research was funded by the grant OPUS from the National Science Centre Poland UMO- 2020/37/B/NZ7/03975.

Institutional Review Board Statement: Not applicable to this study.

Informed Consent Statement: Not applicable to this study. 
Data Availability Statement: The data supporting reported results can be found in Department of Pharmacognosy, Poznan University of Medical Sciences; Department of Pharmaceutical Biochemistry, Poznan University of Medical Sciences; Department of Biotechnology, Microbiology and Human Nutrition, University of Life Sciences in Lublin.

Conflicts of Interest: The authors declare no conflict of interest.

\section{References}

1. Majchrzak-Celinska, A.; Zielinska-Przyjemska, M.; Wierzchowski, M.; Kleszcz, R.; Studzinska-Sroka, E.; Kaczmarek, M.; Paluszczak, J.; Cielecka-Piontek, J.; Krajka-Kuzniak, V. Methoxy-stilbenes downregulate the transcription of Wnt/ $\beta$-catenindependent genes and lead to cell cycle arrest and apoptosis in human T98G glioblastoma cells. Adv. Med. Sci. 2020, 66, 6-20, advance online publication. [CrossRef] [PubMed]

2. Goozee, K.; Shah, T.; Sohrabi, H.; Rainey-Smith, S.; Brown, B.; Verdile, G.; Martins, R. Examining the potential clinical value of curcumin in the prevention and diagnosis of Alzheimer's disease. Br. J. Nutr. 2016, 115, 449-465. [CrossRef]

3. Moody, R.; Wilson, K.; Jaworowski, A.; Plebanski, M. Natural compounds with potential to modulate cancer therapies and self-reactive immune cells. Cancers 2020, 12, 673. [CrossRef] [PubMed]

4. Brancato, V.; Nuzzo, S.; Tramontano, L.; Condorelli, G.; Salvatore, M.; Cavaliere, C. Predicting survival in glioblastoma patients using diffusion MR imaging metrics-A systematic review. Cancers 2020, 12, 2858. [CrossRef]

5. Di Paolo, M.; Papi, L.; Gori, F.; Turillazzi, E. Natural products in neurodegenerative diseases: A great promise but an ethical challenge. Int. J. Mol. Sci. 2019, 20, 5170. [CrossRef] [PubMed]

6. Vila, M. Neuromelanin, aging, and neuronal vulnerability in Parkinson's disease. Mov. Disord. 2019, 34, 1440-1451. [CrossRef]

7. Chang, K.-H.; Chen, C.-M. The role of oxidative stress in Parkinson's disease. Antioxidants 2020, 9, 597. [CrossRef] [PubMed]

8. Thanan, R.; Oikawa, S.; Hiraku, Y.; Ohnishi, S.; Ma, N.; Pinlaor, S.; Yongvanit, P.; Kawanishi, S.; Murata, M. Oxidative stress and its significant roles in neurodegenerative diseases and cancer. Int. J. Mol. Sci. 2015, 16, 193-217. [CrossRef]

9. Misra, S.; Heldin, P.; Hascall, V.C.; Karamanos, N.K.; Skandalis, S.S.; Markwald, R.R.; Ghatak, S. Hyaluronan-CD44 interactions as potential targets for cancer therapy. FEBS J. 2011, 278, 1429-1443. [CrossRef] [PubMed]

10. Chen, J.E.; Pedron, S.; Shyu, P.; Hu, Y.; Sarkaria, J.N.; Harley, B.A.C. Influence of hyaluronic acid transitions in tumor microenvironment on glioblastoma malignancy and invasive behavior. Front. Mater. 2018, 5, 39. [CrossRef]

11. Qiu, J.; Shi, Z.; Jiang, J. Cyclooxygenase-2 in glioblastoma multiforme. Drug Discov. Today 2017, 22, 148-156. [CrossRef]

12. Saghaie, L.; Pourfarzam, M.; Fassihi, A.; Sartippour, B. Synthesis and tyrosinase inhibitory properties of some novel derivatives of kojic acid. Res. Pharm Sci. 2013, 8, 233-242. [PubMed]

13. Yu, H.; Wang, Q.; Sun, Y.; Shen, M.; Li, H.; Duan, Y. A new PAMPA model proposed on the basis of a synthetic phospholipid membrane. PLOS ONE 2015, 10, e0116502. [CrossRef]

14. Patel, K.; Singh, G.K.; Patel, D.K. A review on pharmacological and analytical aspects of naringenin. Chin. J. Integr. Med. 2018, 24, 551-560. [CrossRef]

15. Smeriglio, A.; Barreca, D.; Bellocco, E.; Trombetta, D. Chemistry, pharmacology and health benefits of anthocyanins. Phytother. Res. 2016, 30, 1265-1286. [CrossRef] [PubMed]

16. Lu, X.; Zhao, Q.; Tian, Y.; Xiao, S.; Jin, T.; Fan, X. A metabonomic characterization of (+)-usnic acid-induced liver injury by gas chromatography-Mass spectrometry-based metabolic orofiling of the plasma and liver in rat. Int. J. Toxicol. 2011, 30, 478-491. [CrossRef] [PubMed]

17. Talapatra, S.K.; Rath, O.; Clayton, E.; Tomasi, S.; Kozielski, F. Depsidones from lichens as natural product inhibitors of M-phase phosphoprotein 1, a human kinesin required for cytokinesis. J. Nat. Prod. 2016, 79, 1576-1585. [CrossRef]

18. Studzinska-Sroka, E.; Dubino, A. Lichens as a source of chemical compounds with anti-inflammatory activity. Herba Pol. 2018, 64, 56-64. [CrossRef]

19. Rankovic, B.; Kosanic, M. Lichens as a potential source of bioactive secondary metabolites. In Lichen Secondary Metabolites; Rankovic, B., Ed.; Springer International Publishing: Cham, Switzerland, 2019. [CrossRef]

20. Solarova, Z.; Liskova, A.; Samec, M.; Kubatka, P.; Busselberg, D.; Solar, P. Anticancer potential of lichens' secondary metabolites. Biomolecules 2020, 10, 87. [CrossRef]

21. Fernandez-Moriano, C.; Divakar, P.K.; Crespo, A.; Gomez-Serranillos, M.P. In vitro neuroprotective potential of lichen metabolite fumarprotocetraric acid via intracellular redox modulation. Toxicol. Appl. Pharmacol. 2017, 316, 83-94. [CrossRef]

22. Emsen, B.; Aslan, A.; Togar, B.; Turkez, H. In vitro antitumor activities of the lichen compounds olivetoric, physodic and psoromic acid in rat neuron and glioblastoma cells. Pharm. Biol. 2016, 54, 1748-1762. [CrossRef]

23. Cardile, V.; Graziano, A.C.E.; Avola, R.; Piovano, M.; Russo, A. potential anticancer activity of lichen secondary metabolite physodic acid. Chem. Biol. Interact. 2017, 263, 36-45. [CrossRef] [PubMed]

24. Emsen, B.; Sadi, G.; Bostanci, A.; Aslan, A. In vitro evaluation of cytotoxic, oxidative, genotoxic, and apoptotic activities of physodic acid from Pseudevernia furfuracea in HepG2 and THLE2 cells. Plant Biosyst. 2020, 1-10. [CrossRef]

25. Studzinska-Sroka, E.; Zarabska-Bozejewicz, D. Hypogymnia physode-A lichen with interesting medicinal potential and ecological properties. J. Herb. Med. 2019, 17-18, 100287. [CrossRef]

26. Paluszczak, J.; Kleszcz, R.; Studzinska-Sroka, E.; Krajka-Kuzniak, V. Lichen-derived caperatic acid and physodic acid inhibit Wnt signaling in colorectal cancer cells. Mol. Cell Biochem. 2018, 441, 109-124. [CrossRef] [PubMed] 
27. Butler, M.; Pongor, L.; Su, Y.T.; Xi, L.; Raffeld, M.; Quezado, M.; Trepel, J.; Aldape, K.; Pommier, Y.; Wu, J. MGMT Status as a clinical biomarker in glioblastoma. Trends Cancer 2020, 6, 380-391. [CrossRef] [PubMed]

28. Lee, S.Y. Temozolomide resistance in glioblastoma multiforme. Genes Dis. 2016, 3, 198-210. [CrossRef]

29. Grabowska, K.; Podolak, I.; Galanty, A.; Zaluski, D.; Makowska-Was, J.; Sobolewska, D.; Janeczko, Z.; Zmudzki, P. In vitro anti-denaturation and anti-hyaluronidase activities of extracts and galactolipids from leaves of Impatiens parviflora DC. Nat. Prod. Res. 2016, 30, 1219-1223. [CrossRef]

30. Lim, T.Y.; Lim, Y.Y.; Yule, C.M. Evaluation of antioxidant, antibacterial and anti-tyrosinase activities of four Macaranga species. Food Chem. 2009, 114, 594-599. [CrossRef]

31. Ellman, G.L.; Lourtney, D.K.; Andres, V.; Gmelin, G. A new and rapid colorimetric determination of acetylcholinesterase activity. Biochem. Pharmacol. 1961, 7, 88-95. [CrossRef]

32. Szwajgier, D.; Baranowska-Wojcik, E. Terpenes and phenylpropanoids as acetyl- and butyrylcholinesterase inhibitors: A comparative study. Curr Alzheimer Res. 2019, 16, 963-973. [CrossRef]

33. Rhee, I.K.; van Rijn, R.M.; Verpoorte, R. Qualitative determination of false-positive effects in the acetylcholinesterase assay using thin layer chromatography. Phytochem. Anal. 2003, 14, 127-131. [CrossRef]

34. Kikowska, M.A.; Chmielewska, M.; Wlodarczyk, A.; Studzinska-Sroka, E.; Zuchowski, J.; Stochmal, A.; Kotwicka, M.; Thiem, B. Effect of pentacyclic triterpenoids-rich callus extract of Chaenomeles japonica (Thunb.) Lindl. ex Spach on viability, morphology, and proliferation of normal human skin fibroblasts. Molecules 2018, 23, 3009. [CrossRef] [PubMed]

35. Studzinska-Sroka, E.; Dudek-Makuch, M.; Chanaj-Kaczmarek, J.; Czepulis, N.; Korybalska, K.; Rutkowski, R.; Luczak, J.; Grabowska, K.; Bylka, W.; Witowski, J. Anti-inflammatory activity and phytochemical profile of Galinsoga Parviflora cav. Molecules 2018, 23, 2133. [CrossRef] [PubMed]

36. Chen, X.; Murawski, A.; Patel, K.; Crespi, C.L.; Balimane, P.V. A novel design of artificial membrane for improving the PAMPA model. Pharm. Res. 2008, 25, 1511-1520. [CrossRef] [PubMed]

37. Latacz, G.; Lubelska, A.; Jastrzebska-Wiesek, M.; Partyka, A.; Marc, M.A.; Satala, G.; Wilczynska, D.; Kotanska, M.; Wiecek, M.; Kaminska, K.; et al. The 1,3,5-triazine derivatives as innovative chemical family of 5-HT6 serotonin receptor agents with therapeutic perspectives for cognitive impairment. Int. J. Mol. Sci. 2019, 20, 3420. [CrossRef] [PubMed]

38. Bialonska, D.; Dayan, F.E. Chemistry of the lichen Hypogymnia physodes transplanted to an industrial region. J. Chem Ecol. 2005, 31, 2975-2991. [CrossRef]

39. Rankovic, B.; Kosanic, M.; Manojlovic, N.; Rancic, A.; Stanojkovic, T. Chemical composition of Hypogymnia physodes lichen and biological activities of some its major metabolites. Med. Chem. Res. 2014, 23, 408-416. [CrossRef]

40. Latkowska, E.; Bober, B.; Chrapusta, E.; Adamski, M.; Kaminski, A.; Bialczyk, J. Secondary metabolites of the lichen Hypogymnia physodes (L.) Nyl. and their presence in spruce (Picea abies (L.) H. Karst.) bark. Phytochemistry 2015, 118, 116-123. [CrossRef]

41. Olivier-Jimenez, D.; Chollet-Krugler, M.; Rondeau, D.; Beniddir, M.A.; Ferron, S.; Delhaye, T.; Allard, P.M.; Wolfender, J.L.; Sipman, H.J.M.; Lücking, R.; et al. A database of high-resolution MS/MS spectra for lichen metabolites. Sci. Data 2019, 6, 294. [CrossRef]

42. Fernandez-Moriano, C.; Gomez-Serranillos, M.P.; Crespo, A. Antioxidant potential of lichen species and their secondary metabolites. A systematic review. Pharm Biol. 2016, 54, 1-17. [CrossRef] [PubMed]

43. Studzinska-Sroka, E.; Piotrowska, H.; Kucinska, M.; Murias, M.; Bylka, W. Cytotoxic activity of physodic acid and acetone extract from Hypogymnia physodes against breast cancer cell lines. Pharm. Biol. 2016, 54, 2480-2485. [CrossRef] [PubMed]

44. Fernandes, C.; Costa, A.; Osorio, L.; Lago, R.C.; Linhares, P.; Carvalho, B.; Caeiro, C. Current standards of care in glioblastoma therapy. In Glioblastoma; De Vleeschouwer, S., Ed.; Codon Publications: Brisbane, Australia, 2017; pp. 197-241. Available online: https: / / www.ncbi.nlm.nih.gov / books/NBK469987/ (accessed on 10 February 2021).

45. Yoshino, A.; Ogino, A.; Yachi, K.; Ohta, T.; Fukushima, T.; Watanabe, T.; Katayama, Y.; Okamoto, Y.; Naruse, N.; Sano, E.; et al. Gene expression profiling predicts response to temozolomide in malignant gliomas. Int. J. Oncol. 2010, 36, 1367-1377. [CrossRef] [PubMed]

46. Reddy, R.G.; Veeraval, L.; Maitra, S.; Chollet-Krugler, M.; Tomasi, S.; Devehat, F.L.; Boustie, J.; Chakravarty, S. Lichen-derived compounds show potential for central nervous system therapeutics. Phytomedicine 2016, 23, 1527-1534. [CrossRef] [PubMed]

47. Leuci, R.; Brunetti, L.; Poliseno, V.; Laghezza, A.; Loiodice, F.; Tortorella, P.; Piemontese, L. Natural compounds for the prevention and treatment of cardiovascular and neurodegenerative diseases. Foods 2020, 10, 29. [CrossRef]

48. Jin, S.G.; Jeong, Y.I.; Jung, S.; Ryu, H.H.; Jin, Y.H.; Kim, I.Y. The effect of hyaluronic acid on the invasiveness of malignant glioma cells: Comparison of invasion potential at hyaluronic acid hydrogel and matrigel. J. Korean Neurosurg. Soc. 2009, 46, 472-478. [CrossRef]

49. Bruno, M.; Trucchi, B.; Burlando, B.; Ranzato, E.; Martinotti, S.; Akkol, E.K.; Suntar, I.; Keles, H.; Verotta, L. (+)-Usnic acid enamines with remarkable cicatrizing properties. Bioorg. Med. Chem. 2013, 21, 1834-1843. [CrossRef]

50. Bauer, J.; Waltenberger, B.; Noha, S.M.; Schuster, D.; Rollinger, J.M.; Boustie, J.; Chollet, M.; Stuppner, H.; Werz, O. Discovery of depsides and depsidones from lichen as potent inhibitors of microsomal prostaglandin E2 synthase-1 using pharmacophore models. ChemMedChem 2012, 7, 2077-2081. [CrossRef]

51. Jiang, J.; Qiu, J.; Li, Q.; Shi, Z. Prostaglandin E2 signaling: Alternative target for glioblastoma? Trends Cancer 2017, 3, 75-78. [CrossRef] 
52. Bartels, A.L.; Leenders, K.L. Cyclooxygenase and neuroinflammation in Parkinson's disease neurodegeneration. Curr. Neuropharmacol. 2010, 8, 62-68. [CrossRef]

53. Higuchi, M.; Miura, Y.; Boohene, J.; Kinoshita, Y.; Yamamoto, Y.; Yoshimura, I.; Yamada, Y. Inhibition of tyrosine activity by cultured lichen tissues and bionts. Planta Med. 1993, 59, 253-255. [CrossRef] [PubMed]

54. Stojanovic, G.; Zlatanovic, I.; Zrnzevic, I.; Stankovic, M.; Stankov Jovanovic, V.; Zlatkovic, B. Hypogymnia tubulosa extracts: Chemical profile and biological activities. Nat. Prod. Res. 2018, 32, 2735-2739. [CrossRef] [PubMed]

55. Hawryl, A.; Hawryl, M.; Hajnos-Stolarz, A.; Abramek, J.; Bogucka-Kocka, A.; Komsta, L. HPLC Fingerprint Analysis with the antioxidant and cytotoxic activities of selected lichens combined with the chemometric calculations. Molecules 2020, $25,4301$. [CrossRef] [PubMed]

56. Solhaug, K.A.; Lind, M.; Nybakken, L.; Gauslaa, Y. Possible functional roles of cortical depsides and medullary depsidones in the foliose lichen Hypogymnia physodes. Flora 2009, 204, 40-48. [CrossRef]

57. Naoi, M.; Shamoto-Nagai, M.; Maruyama, W. Neuroprotection of multifunctional phytochemicals as novel therapeutic strategy for neurodegenerative disorders: Antiapoptotic and antiamyloidogenic activities by modulation of cellular signal pathways. Future Neurol. 2019, 14, FNL9. [CrossRef]

58. Shepardson, N.E.; Shankar, G.M.; Selkoe, D.J. Cholesterol level and statin use in Alzheimer disease: II. Review of human trials and recommendations. Arch Neurol. 2011, 68, 1385-1392. [CrossRef] 